\title{
To What Extent Educational Planning and Policy Decision ought to Be Guided by Economic Considerations - A Case Study on Recent Educational Developments of Hong Kong
}

\author{
Margaret Wai Ki LO \\ B3 16/F Park View Court \\ No. 1 Lyttelton Road, Mid-levels, Hong Kong \\ Tel: (852) 91900532 E-mail: mlo@hkeaa.edu.hk \\ Sponsoring Organisations: HKU SPACE, Hong Kong, University of Nottingham, UK
}

\begin{abstract}
The ascendance to popularity of the liberal ideologies and the concepts of political economy of education will be put forward as the root cause for an increasing subordination of education objectives to national economic goals. Through a case study of the educational development of Hong Kong, this paper will evaluate the extent to which educational planning and policy decision should be guided by economic considerations. Although the rapid economic growth of Hong Kong and the rapid expansion of its education system in the past decades took place in parallel, there is no evidence that Hong Kong's economic success is directly brought about by its education. It will be concluded that apart from economic contributions, education has its own intrinsic values. While economic considerations are useful for planning and policymaking at a macro level, it may not be appropriate to indiscriminately apply economic principles in an intrusive way to direct the priorities of institution management and classroom teaching.
\end{abstract}

Keywords: Educational planning, Political economy, Education reform, Human capital

\section{Liberalism}

Different people view education from different perspectives, but there could be no denying that for most, if not all, policymakers nowadays, education is a major state planning apparatus serving national economic goals. This phenomenon is closely associated with the rising influence of the classical liberal and neoliberal beliefs that the most effective way to govern a state is to apply market rules. These liberal philosophy and ideologies have formed the guiding principles and rationales for the organization of the western capitalist societies and their social, political and economic reproduction. This is also true in education as a major state planning apparatus. Hence in evaluating the extent to which educational planning and policy decision ought to be guided by economic considerations, it is useful to trace the origins of the "old" or classical liberalism which had its beginnings in the seventeenth century and gradually rose to prominence until the last decades of the nineteenth century when it became challenged by welfare liberalism and the "new" or "neoliberalism".

\subsection{Classical liberalism}

As a philosophical tradition, classical liberalism is not a homogenous doctrine with rigid objectives. Jaggar argues that it has a number of forms, not all of which are internally consistent, but are unified by an underlying conception of human nature. (Jaggar 1983 p. 28) Gray puts forward that liberalism has no single unchanging essence but that there are certain distinctive features which characterize it as a discourse. (Gray 1968 p. $x$ to xi) Notwithstanding different possible approaches to the study of classical liberalism, it is possible to distinguish liberalism into three forms, i.e. political liberalism, social democratic liberalism and economic liberalism. Economic liberalism in particular has far-reaching implications for educational planning and policymaking.

The early economic liberals set limits to the state's capacity to rule by representing society, and the arena of market exchanges, as natural arenas which could regulate themselves according to natural laws intrinsic to them. For these purposes, the doctrine of natural rights implied limitations to the sovereign's power, preventing the government from acting without restrictions. Far from engendering endless conflict, this view asserted the belief that individuals who pursued their own ends without regard to the interests or needs of others, produced as the unplanned and unintended result, the harmony and prosperity of the whole society. This conception of a natural synergy between self-interested individuals, and the peace, harmony and progress of society became widely circulated in the eighteenth century. These individual-society relations were structured by Adam Smith as invisible hand theory. Smith makes it clear that the hand can bring about the benefits that it is capable of only if it remains invisible, i.e. stays at the background and intervenes only for protection of individual rights or 
removing obstacles of a fair competition. There would be little benefit resulting from any active attempt to direct the hand for the public good.

The invisible hand theory is a commitment to laissez faire. Given the nature of human beings as interest-optimizers, a de-regulated competitive market system provides the best environment for them to utilize their abilities to optimize their goals. This self-regulating mechanism is believed to be far more efficient and morally superior to government regulation or any other forms of external forces.

For economic liberals, choices are made according to self-interests and hence individuals as interest-optimizers are isolated autonomous choosers, free from the restrain of contracts. These ideas are in contradiction to the political liberals' contract conceptions of right, in which individual interests are subordinated to a system of rights within contracts. This shift from "contract" towards "invisible hand" conception signalized a series of changes in rationalization in the eighteenth century, which converged to form the basis of political economy as science of society or a way of governing. (Olssen, Codd \& O’Neil 2004 p. 79)

Political economy of education started to take shape when the rules of this "science of society", which are essentially economic in nature, were applied as guiding principles to the running of education. The "self-interested maximizer" conception mentioned earlier, which assures that individuals are pre-social and basically solitary, with needs and interests which are separated from or opposed to others, is the starting point of liberal philosophy. Expressed in educational discourse, 1) one's academic achievement is determined by one's own inborn capability and efforts, and has not much to do with external factors, such as race, social class and gender; 2) education is for private good and it is the parents' obligation to educate their children and 3) schools are considered having fulfilled their educational duties if they provide choices and equal opportunity for all to learn through a private market. To regulate the education sector, the state should adopt a negative conception of state power limited to defense of laissez-faire and social contracts based on the theory of rights or utility.

\subsection{Neoliberalism}

Neoliberalism, once marginalized by the ethically sound welfare liberalism of the late nineteenth century and the economics of Keynesian demand management in the twentieth century, is a continuation of classical liberalism right up to the twentieth century. In the shift from classical liberalism to neoliberalism, on top of the concepts of 1) self-interested individuals; 2) invisible hand and 3) laissez faire, there is a change from homo economicus, who naturally behaves out of self-interest, and is relatively detached from the state, to manipulatable man, who is created by the state and who is continually encouraged to be "perpetually responsive" to the demands of the state. (O'Neil 1996 p. 403 - 16) As a reaction in a time of universal welfare, the neoliberals proposed the necessities for some forms of vigilance and control over indolence. In this new model, the state has taken it upon itself to keep all up to the mark and see to it that all are making a continuous "enterprise of themselves" (Gordon 1991 p. 44) in what claimed to be a way to "govern without governing". (Rose 1993 p. 298)

Alongside with this shift, is "the celebration of, and assumed superiority of, market mechanisms to ensure economic prosperity, the maximization of individual freedom and its provision of a base for all social interactions. Market forces should be allowed to operate as widely as possible within a social order that is understood to be capable of almost total self-regulation. There is thought to be no need to the state intervention other than to minimize market distortion or offset certain dysfunctions." (Olssen, Codd \& O'Neil 2004 p. 137)

Neoliberalism in education essentially refers to 1) freedom of choice in schooling and hence the state should refrain from deciding what kind of education is best for individuals; 2) education should be responsive to the needs of the clients and market; 3 ) education is publicly provided and privately accessed; 4) education will be used for career advancement of individuals and 5) education is a commodity which could be traded in the market and the skills acquired in education will reflect the nature of the market. Besides, the neoliberal conception of a positive form of state power in ensuring all are enterprising and competitive individuals has profound implications on the institutionalization of the education sector and the management of educational institutions in the twenty first century. This point will be elaborated in Sections 4, 5 and 6.

Neoliberalism, and the variants within neoliberalism tradition, including Monetarism, Public Choice Theory, Agency Theory, Transaction Cost Economics and Human Capital Theory, has strong impact on the formulation of social, economic and monetary policies in the recent decades among capitalist countries. Human Capital Theory in particular has dominated the education planning and policy decision in the OECD and many other countries.

\subsection{Human Capital Theory}

Human Capital Theory emerged in modern form in the 1960s. Following the work of Theodore Schultz, E.F. 
Denison and Gary Becker, there was a renewed concern for investment in education. As Schultz puts it:

"I propose to treat education as an investment in man and to treat its consequences as a form of capital. Since education becomes a part of the person receiving it, I shall refer to it as human capital.... It is a form of capital if it renders a productive service of value to the economy." (Shultz 1960 p. $571-583$ )

According to E.F. Denison, improved education was one of the major factors contributing to a nation's economic growth. (Denison 1962) Then in 1964, a major publication by Gary Becker, Human Capital: A Theoretical and Empirical Analysis with Special Reference to Education, maintained that education was "the most important single determinant" of economic growth. (Denison 1962 p. 45) He saw human capital as a commodity tradable according to the principles of market exchange.

The main propositions of Human Capital Theory are that education and training enhance one's cognitive capacity and hence productivity which is likely to lead to increased earning. A nation's human capital is the sum of skills, talents and knowledge embodied in its people. Human Capital Theory puts a direct link between education and a nation's wealth. Since then, politicians have started to make conscious application of Human Capital Theory on policy formulation aiming at enhancing the economic power or economic competitiveness of their respective countries.

It is probably not unfair to say that Human Capital Theory and its corresponding manpower analysis is now out of fashion partly because educational planning through manpower forecasts failed to deliver what it claims. This point will be elaborated under Section 5 of this paper. There is also a shift in focus of educational planning and policy decision from central planning towards market solutions.

\section{Ascendance of political economy of education}

The political economy of education as a modern field of study has grown rapidly in the recent decades. In the coming paragraphs, the social factors which have brought about the ascendance of political economy of education will be discussed.

\subsection{Compulsory education}

Since the mid-twentieth century after World War II, partly due to human right considerations, partly due to the rationale that nations should be competing by economic (instead of military) power, government funded education has been expanding among the industrialized or developed countries into compulsory education which in turn, has been expanding from general education to vocational education and training provided through employers, and from primary education, to secondary and higher education. In parallel to this, education has gradually stood out as a major agenda item, being scrutinized and discussed in the context of policy decision. In order to justify the policy direction and ensure the policy direction will deliver results, close links are drawn by governments between education and economic competitiveness amongst other things:

"Initial training institutions should also make positive efforts to ensure that future teachers understand the part that their subject plays in the economic and cultural life of their society, and that they have sufficient understanding on the economic foundations of that society, and the role of industry and commerce in wealth creation, to be able to pass on to their pupils both information about and respect for industrial and commercial activity." (Bailey 1984 p. 168) Note 1

"Pupils need to acquire an understanding of the economic basis of society and how wealth is created. Close links between the schools and local industry and commerce are valuable in this context, but also have wider benefits." (Bailey 1984 p. 169) Note 2

\subsection{Globalization and advancement in technology}

On top, the pressing need for enhancing economic competitiveness through education has been fueled by globalization and advancement in technology, which result in the popular sloganising of knowledge-based economy in the recent decades. Against this backdrop, OECD revitalized the human capital concepts by emphasizing the importance of investment in education in the 1980s. In its monograph, "Structural adjustment and economic performance", OECD once again represented education as an important source of flexibility and responsiveness in relation to the rapid technological and economic change. (OECD 1987)

However, the emphasis on education for economic growth does not only take place in OECD countries. According to the research of Guthrie and Pierce in 1990, the new international economy is reshaping education in many industrialized nations. There is a common need to produce an education system that will provide each nation with the human resources in a modern and competitive economy. The international nature of national economic problems has stimulated government officials to take action to improve their nations' human resources. 
Such pressures are mounting and reforms will continue to be made until a nation's competitive position is assured. Failure to have an educational system that provides a highly educated and adaptable workforce will lead to economic decline and a lower living standard. (Guthrie \& Price 1990 p. 179 - 205) The following remark by the former British Prime Minister Mrs. Thatcher in her defense of the 1988 Education Reform Act is self-explanatory:

"To compete successfully in tomorrow's world against Japan, Germany and the United States, we need well-educated, well-trained creative young people. But if education is backward today, national performance will be backward tomorrow." (Moon, Murphy \& Raynor 1989 p. 227) ${ }^{\text {Note } 3}$

\subsection{Expansion in education expenditure and the need for its justification}

With all these demands on education, government expenditure on education naturally grows.

"Public funding of education is now a social priority, even in OECD countries with little public involvement in other areas....... Typically, from 1995 to 2004, public expenditure on education grew faster than total public spending, and as fast as national income.” (OECD 2007 p. 225)

Alongside with the growing education expenditure, there is a growing need for justifying such expenditure. More important is the question of how to settle priorities when many other services are also being described by their protagonists as being essential. More and more economic values and expectation are lumped onto educational plans and policies. Debates amongst politicians on how best to fund education to achieve the most return, improvement on cost effectiveness of education, manpower planning to stay ahead of the global economic competition, etc. have now moved to the centre stage of politics. Failure to achieve good economic results through education may even lead to embarrassment or decline of the ruling party or the government.

\section{Policy direction to promote economic competitiveness through education in Hong Kong}

In the sections foregone, reasons behind the emphasis on economic considerations in educational planning and policy decision have been analysed. It is worth examining to what extent economic considerations should be put at the centre-stage of educational planning and policy decision. With a dense population and yet lack of natural resources, Hong Kong relies heavily on its human capital as a resource. Hence Hong Kong would make a good candidate for a case study on this.

First of all, it has to be established whether educational planning and policy decision in Hong Kong are indeed influenced by economic considerations. This will be done through examining the policy directions and the corresponding policy support measures implemented by the Hong Kong Government.

For three consecutive years from 1994 through 1996, it was found in the annual Policy Address of the Hong Kong Government that forecasts of the supply and demand for special skills and qualifications were used as important data to support the formulation of educational plans. It was pointed out in both the 1994 and 1995 Policy Addresses that the continuing shift from manufacturing industry to the service sector had created a demand for higher standards at both ends of the educational scale, i.e. from those who left school after Secondary Three and also to those who went on to post-graduate education. At the same time, parents and students had increasingly higher expectations of the educational system. In order to stay competitive, it would be necessary to ensure that the school curriculum continued to meet both the changing needs of the economy. To allow students more choice of academic, practical and technical subjects, it would also be necessary to broaden the core curriculum at secondary and sixth form levels. (Hong Kong Government 1994 p.12, 1995 p. 22) The 1996 Policy Address introduced the point that the education system had to prepare students for a world of radical change. (Hong Kong Government 1996 p. 30)

The handover of sovereignty of Hong Kong by the British Government to the People's Republic of China in 1997 did not change this emphasis. In his speech at the Special Administrative Region's Establishment Ceremony, the first Chief Executive of the Hong Kong Special Administrative Region, Mr. Tung Chee Hwa, said:

"We face keen competition in trade and services.... Education is the key to the future of Hong Kong. It provides a level playing field for all, and the human resources required for further economic development."

The same message recurred again and again in the subsequent Policy Addresses:

"To take Hong Kong forward in an increasingly competitive world, we must give education top priority. (Tung 1998 paragraph 89) ...... In the next century, knowledge-based economies will take the lead in the world. It is imperative that our education system keeps pace with the times. (Tung 1999 paragraph 52) ....... The education system of old can no longer meet the challenges of the new age ..... therefore, without sweeping reforms of our 
education system, the quality of our education would not be able to meet the requirements for social development and the community's expectations. (Tung 2000 paragraph 53)"

In Policy Addresses from 2003 to 2005, education was taken as a form of investment.

"One crucial means of promoting economic restructuring is by investing in education. Only by developing our own local human resources and providing opportunities for continuing education for people of all walks of life can we prepare ourselves for the changes in the marketplace. (Tung 2003 paragraph 20) ..... Currently, education accounts for $25 \%$ of government expenditure. As I have said on many occasions, every cent spent on education is an investment, not an expense. (Tung 2004 paragraph 43) ..... We will continue to promote life-long learning to upgrade the competitiveness of our workforce. (Tung 2005 paragraph 56)"

It is worth pointing out here that the proportion of public expenditure on education in Hong Kong was only something between $13 \%$ and $20.1 \%$ in the 1970 s and 1980 s (Cheng 1992 p. 216). $25 \%$ of government expenditure on education is a very high percentage compared with other countries. On average, OECD countries devoted only $13.4 \%$ of total public expenditure to education in 2004. (OECD 2007 p. 225)

The second Chief Executive of Hong Kong, Mr. Donald Tsang, apart from furthering the direction of "investing in education", he introduced an even more aggressive policy direction of attracting outstanding students from elsewhere to study in Hong Kong in order to "enlarge our pool of talents" and "enhance the quality of our population”. (Tsang 2007 paragraph 93, 2008 paragraph 49)

The emphasis of the Hong Kong Government on economic considerations in educational planning and policy decision is overwhelming.

\section{Educational measures implemented in Hong Kong to enhance economic competitiveness through education}

In order to ensure its education system would deliver the expected economic objectives, the Hong Kong Government introduced a series of education reforms. Some of the most high-profile policy support measures will be discussed in the upcoming paragraphs.

\subsection{Language Proficiency Assessment for Teachers}

Economic considerations are behind the emphasis of the Government on language proficiency. As early as 1990, in the Fourth Education Commission Report:

"Hong Kong is an international business, financial and trading centre. English therefore has an important place in the economic life of our community. In order to maintain Hong Kong's international position, we have to ensure that we produce sufficient well educated people able to communicate in English and Chinese." (Education Commission 1990 paragraph 6.4.7)

It is the Government's policy for Hong Kong students to be biliterate (i.e. master written Chinese and English) and trilingual (i.e. speak fluent Cantonese, Putonghua and English):

"It is the SAR Government's goal to train our people to be truly biliterate and trilingual. To ensure that all teachers achieve a necessary standard of language ability, we have established language benchmarks for those teaching English in junior secondary schools and Putonghua in primary schools. The relevant training programmes and examinations will start next year. Thereafter, newly-appointed teachers must pass the language benchmarks." (Tung 1999 paragraph 69)

The Language Proficiency Assessment for Teachers (LPAT) was introduced in 2000 as the language benchmark test for English Language and Putonghua teachers. All in-service language teachers concerned had to either pass LPAT or complete the stipulated course by 2006. Starting from the academic year of 2004, all new language teachers are required to have the minimum requirement of LPAT met before they can start teaching.

\subsection{Workplace English Campaign}

To enhance English standard of working people, the Government launched the Workplace English Campaign in 2000 to heighten public awareness of the importance of having a good command of English in a workplace environment. The campaign promotes the Hong Kong Workplace English Benchmarks which spell out the standard of English in writing and speaking and the employees of different industries in Hong Kong should strive to attain. Working people can apply for refund for English Language courses completed if they manage to pass the stipulated range of English tests.

\subsection{Quality assurance in school education}

One of the major objectives of the neoliberal reforms in education in OECD countries was to improve quality 
through enhancing accountability in order to stay ahead of competition. These changes are not new to schools in Hong Kong.

According to the recommendation of the Education Commission as summarized in Chapter 8 of its Report No. 7, quality school education should be achieved through 1) school-based management; 2) cooperation of key-players through school system; 3) self evaluation and 4) external audit.

The key elements of school-based management include: development of formal procedures for setting school goals and evaluating progress towards these goals; provision of documents to outline the schools' profiles, development plans and budgets, and means of evaluating progress; preparation of written constitutions for the school management committees; participation of teachers, parents and alumni in school management, development, planning, evaluation and decision making; and development of formal procedures and resources for staff appraisal and staff development according to teachers' needs. The main feature of cooperation of key-players is the formal participation of external stakeholders, notably parents and alumni, in school management. Self-evaluation should be conducted annually to review progress made according to set goals, identify areas for improvement and plan for necessary follow-up actions. For external audit, due to public concerns, the Education Commission recommended the Government to commission a separate study on the way forward.

Amidst resistance from schools and years of public debates, the above recommendations were implemented through the approval of the Education Amendment Ordinance 2004 (Amendment Ordinance) by the Legislative Council in July 2004.

\subsection{Quality assurance in pre-school education}

A series of similar quality assurance mechanisms were introduced in nurseries and kindergarten from 2001 through 2004, including quality assurance inspection, uploading quality assurance reports on government website for information of stakeholders, setting qualifications requirements for teaching and administration staff and promotion of internal evaluation through external audit. (Education Bureau 2003 p. 7)

\subsection{Territory-wide System Assessment}

Another neoliberal theme for education reform is enhancing transparency of school performance so as to enhance the possibilities for standards to be upheld. The Government introduced the Territory-wide System Assessment (TSA) in 2003 as proposed by the Education Commission in 2000. (Education Commission 2000) TSA consists of three subjects: Chinese Language, English Language and Mathematics. It is administered at Primary Three, Primary Six and Secondary Three once a year at all primary and secondary schools in Hong Kong. The main purpose of the TSA is to provide the Government and school management with information on school performance in key learning areas for school improvement purposes.

\subsection{Expansion of vocational education and employees retraining}

In consultation with employers, the Government decided to provide a grant of HK\$500 million to the Employees Retraining Board to enable it to provide courses which could better answer the needs of employers, including some tailor-made ones. Besides, the Hong Kong Institute of Vocational Education, the largest vocational training provider of Hong Kong, with 7 campuses over different parts of the territory, was reorganized so that their courses could be upgraded and more attuned to the needs of employers. (Tung 1998 paragraphs 106 - 108)

\subsection{Manpower supply and demand projection}

The Government embarked on a large-scale overall manpower projection the first time in 1990. The aim of the projection was to arrive at a desirable educational mix for a projected population in five years for educational planning and policy decision. Since then, this projection has become a regular exercise of the Government for ensuring education can answer manpower needs. The findings of the projection to 2005 released in November 2000 as summarized in Table 1 prompted the Government to implement a series of lifelong learning initiatives, which will be elaborated in Section 4.8, to enhance the education level of Hong Kong people in general.

\subsection{Promotion of lifelong learning}

Tung Chee Hwa, the first Chief Executive of the Hong Kong Special Administrative Region under the People's Republic of China, believed that Hong Kong could no longer sustain its competitive edge and transform from a service-based to a knowledge based economy if the colonial elitist education system, limiting the opportunities for higher education only to a handful of the academically capable ones, were to continue. Tung adopted a typical neoliberal approach in promoting lifelong education mainly through collaboration with NGOs and private sector but provision of subsidies to learners as consumers, and introduction of indirect control on course 
providers through quality assurance mechanisms. The following are only some of the major lifelong-education policy support measures introduced during the Tung Chee Hwa regime:

4.8.1 Extend Non-means Tested Loan Scheme to include some 80000 students on self-financing course in government-funded tertiary and post-secondary institutions (Tung 1999 paragraph 77)

4.8.2 Within 10 years, increase senior secondary school leavers to receive tertiary education to $60 \%$ (resulting in the introduction of sub-degree and Associate Degree programmes) (Tung 2000 paragraph 66)

4.8.3 Develop a lifelong learning ladder, and study the implications of establishing a qualifications framework (Tung 2000 paragraph 69)

4.8.4 Accept the Education Commission's proposal of an Education Reform with lifelong learning as its objectives and central theme (Tung 2000 paragraph 54 - 56)

4.8.5 Grant HK\$5 billion to set up a Continuing Education Fund to subsidize continuing education and training programmes to stimulate lifelong learning in the community (Tung 2001 paragraph 54)

4.8.6 Increase second and third year places in local universities to provide further opportunities for Associate Degree graduates from 2005 to 2007 (Tung 2005 paragraph 56)

From the above, it can be seen that educational planning and policy decision in Hong Kong has been very much influenced by economic considerations. In order to establish to what extend educational planning and policy decision should be guided by economic considerations, it will be examined 1) how applicable Human Capital Theory (which has been frequently quoted in policy addresses of the Hong Kong Government) is to Hong Kong; and 2) how effective Hong Kong's education is in enhancing its competitiveness.

\section{How applicable is Human Capital Theory to Hong Kong?}

One of the basic rationales behind investment in education is that education increases earnings by augmenting the capability or productivity of individuals and hence the cost of education can be justified by future return. Economists, such as T. Schultz, G. Becker, J. Mincer, etc. developed elegant frameworks and models to evaluate the efficiency of education. Such evaluation tools in general involve contrasting the lifetime earnings of the more educated with the less. The difference is expressed as a net return to education and is then compared to the cost involved in education. The findings of some research projects conducted in Hong Kong using these tools do seem to prove the cost-effectiveness of investment in education.

Liu used a production function approach to measure the importance of human capital investment in accounting for productivity growth in the manufacturing sector. He discovered that in non-recessionary years during the $1970 \mathrm{~s}$, it accounted for $2 \%$ to $4 \%$ of the growth in average labour productivity. The growth rate of output per capita for the manufacturing sector in the period was $6 \%$ to $7 \%$. This implied that increases in human capital stock alone can account for about half of the growth in average productivity. (Liu 1992) Though Liu included in his research human capital investment other than education, based on Denison's methodology (Denison 1962), he estimated that the human capital formation due to investment in formal education alone was as large as HK\$12 345.3 million in 1986, i.e. about one-fifth of the size of the fixed capital formation.

Kwok used the 1976 and 1981 population by-census and the analytical tool developed by Jacob Mincer (Mincer 1974) to estimate earnings of men. He discovered that among men, the private rate of return to upper secondary education was between $12.5 \%$ and $15.5 \%$, and that for university education was between $16.5 \%$ and $21.5 \%$. (Kwok 1992)

It is interesting to note the change of return rates of education over time in findings of Wong. He used data from the 1976, 1981, and 1986 population census and by-census to estimate the private and social rates of return to upper secondary, matriculation and university education for men. His methodology was based on the pioneering work of G. Becker. His findings can be summarized in Table 2. (Wong 1992)

Despite the differences in methodology, Kwok's findings were not too different from those obtained by Wong. However, over the period, there was a clear pattern of rising rates of return to university education, but falling rates of return to upper secondary and matriculation education. Wong explained that this was primarily the result of a shift in the demand for more educated labour, which was not matched by increases in its supply. It can be seen here that the balance between cost and benefit of education is subject to changes in the supply and demand of labour type. If there were an over-supply of university graduates, then university education would no more be any guarantee of return. In fact, the same rule of supply and demand can be applied to any educational levels. This means that cost-benefit patterns of education can vary due to environmental factors and education does not necessarily enhance earning power. 
A closer examination of the assumptions behind the cost-benefit analysis of the above three research projects can easily reveal the extreme difficulty, if not impossibility, in obtaining the data necessary to calculate the cost and benefit of education to establish the cost-benefit pattern of education.

In Liu's work, for educational investment in human capital, he included two items, which were direct resource cost and earnings foregone of the students. Earnings foregone of students were measured by the earnings of those of the same age who took up employment after completing a lower level of schooling. Wong and Kwok did the same in their respective papers. However, educational investment in human capital should be far more complex than direct resource and earnings forgone.

"Conceptually, the costs of a person's education are taken to be the opportunity costs, that are the full value of the hours sacrificed to education, and this in turn can theoretically be estimated from the monetary valuation of all the benefits he could have enjoyed had he not spent the time on education. One alternative use of his time could be leisure. But it is difficult enough to place a money value on the leisure of any one person let alone having to face the problem of aggregation so as to include all those who are being considered for education." (West 1979 p.114)

Given that there are always changes in market situations, one can hardly be certain that the earning of school leavers today can be compared to earning foregone of students graduating in a few years' time. Liu chose to study the relationship between human capital investment and productivity growth of the manufacturing industries of Hong Kong in 1970s when Hong Kong experienced a continuous phenomenal average growth rate of real gross domestic product per capital of $5.83 \%$ per annum. Within the same period, it was coincident that secondary and tertiary education also rapidly expanded ${ }^{\text {Note } 4}$. Hence he could easily prove the positive correlation between the two. Possibilities were with expansion in manufacturing industries only and no expansion in higher education at all, salaries might still keep increasing in a similar way. Moreover, the same research might arrive at some opposite findings if conducted in a period with expansion in education in a recessionary situation.

Wong pointed out in his paper that the cost-benefit patterns of education could vary according to the supply and demand of labour type as mentioned earlier. Further to that, he showed in his paper how different assumptions in cost components could lead to different sets of findings. Based on social rates of return of education in 1986 as shown in Table 2 above, one may deduce that there was room for increasing investments in university education relative to other levels of education then. However, according to Wong, the calculated direct social cost of university education did not reflect the total opportunity foregone of running the university since the capital costs were not available. "The universities have relatively large stocks of buildings and land. The market value of these services may be quite substantial." He went on to say that "if the unmeasured components is above HK $\$ 18$ 729 per student or totals HK\$246 473640 , then the social rate of return to university education would be equal to or less than that of matriculation. If the unmeasured amount is larger than HK\$35 733 per student or totals HK\$470 722680 , then the social rate of return to university education would be equal or less than that of upper secondary education. If the unmeasured amount is larger than HK\$607 000 per student or totals HK\$7988 120 000 , the social rate of return to university education becomes negative."

Kwok found in his study that after controlling years of schooling and experience, public sector employees were paid $24 \%$ to $36 \%$ more than private sector employees and single women were paid $10 \%$ to $15 \%$ less than men. Apart from environmental factors, income can also be affected by choice of career and the sex of individuals. This finding further undermines the possibility of independent assessment of contribution of education to lifetime earning.

Factors which undermine the income differential approach in assessing the cost-effectiveness of education are not limited to the above. Higher income may be partly due to superior intelligence or ambition. High rates of return may persist in certain sectors, not directly because of wider investment in the education appropriate to such occupations, but because of market imperfection, such as the especially strong monopoly power in these sectors. "The general point is that we must be on guard against applying hastily the results of the cost/benefit studies of statisticians who draw upon data set in an environment assumed to be 'given'..... To have indiscriminate educational campaigns and surges is the wrong policy and simply to proclaim that education 'as a whole' pays is mere sloganising." (West 1979 p. 117 - 118)

The cost and benefit of education consist of a massive range of inter-related variables. Based on the various research projects discussed, education may have contributed to economic growth, but it is not a guarantee for economic return. According to the rule of demand and supply, in normal competitive situation, the value of education will in fact diminish in face of more supply. Over emphasis on economic values of education and indiscriminate application of Human Capital Theory by politicians in educational planning and policy decision 
could be misleading or raising false hope.

\section{How effective is Hong Kong's education in improving its competitiveness?}

\subsection{Has Hong Kong's overall competitiveness been improved?}

According to the key economic indicators published by the Hong Kong Government, the economic situation of Hong Kong is indeed on the rise in the last 5 years, with GDP growing on an average of approximately $5.5 \%$ a year, value of exports approximately $10 \%$; wage remains at a relatively low level of approximately $0.6 \%$ and the magnitude of unemployment 3.5\% over the years. (Hong Kong Government 2009 p. 14 - 16)

However, if taking a wider perspective to examine Hong Kong's competitiveness at an international level, it can be found that since the introduction of the initiatives highlighted above for enhancing the competitiveness of Hong Kong in the last decade, the ranking of Hong Kong on the Global Competitiveness Index issued by the World Economic Forum has been almost a standstill from $13^{\text {th }}$ in 2000 to $11^{\text {th }}$ in 2009. It is however interesting to note in the 2005 Global Competitiveness Report that Hong Kong's ranking declined significantly from $21^{\text {st }}$ to $28^{\text {th }}$ because of "concerns over favouritism by government officials and growing bureaucracy"Note 5 . Social capital $^{\text {Note } 6}$ does count as one of the major criteria for competitiveness ranking. In fact the relatively high competitiveness ranking enjoyed by Hong Kong is partly due its free trade policy which is a legacy of the British colonial rule and can be taken as a kind of cultural capital ${ }^{\text {Note }} 7$ differentiating Hong Kong from the rest of the Asian countries among which it is competing. The competitiveness of Hong Kong has also benefited from being the window and a part of China - the biggest booming economy of the world. This geographical and hereditary advantage of Hong Kong should again be counted towards its stock of social and cultural capital.

To enhance competitiveness, it is not sufficient simply to take into consideration factors which are directly economic. There are different interpretations of "capital" and there are different aspects of competitiveness.

\subsection{Can vocational education answer the needs of employers?}

Vocational education and employees retraining for the unemployed (which is basically another form of vocational training) is meant to serve the needs of employers. However, further scrutiny reveals that employers in Hong Kong for the most part, do not value vocational expertise so highly. This can be demonstrated through their remuneration strategy and requirements for recruits.

Waters examined the financing and costing of craft and technician education in Hong Kong from 1967 to 1987. In order to better satisfy economic needs, according to Waters, the Hong Kong Government put a lot of emphasis on vocational education, and it was why a second polytechnic was established during the recession. Despite this emphasis, due to substantial differentials in pay between craftsman and a degree holder, and the high cost of technical education, the return to technical education was much lower than that of general education. (Waters 1992)

According to the findings of Chung, vocational education in Hong Kong is in fact not even serving much economic purpose. Chung showed that while the private benefits of vocational education were higher than those of general education, it was only true for certain types of vocational education. He also found that many students who received vocational education ended up working in industries for which they were not trained for. High attrition rates reduce the effective rates of return to vocational education. (Chung 1992)

Regarding requirements for recruits, employers sometimes do require specified expertise in certain areas and would look to vocational education to fulfill such needs. However, these may represent only a small proportion even of specialist university graduates. The reason is understandable. Even at the professional level, on top of undergraduate courses, such as law, accountancy, financial management, postgraduate study, certification and actual professional practice are required before a professional qualification can be obtained. Thus to become an accountant, a financial analyst, a solicitor, one need not pursue related courses at school, sometimes not even at undergraduate level.

Employers are in the main not only looking for specific expertise or skills, but also for a range of abilities that may be classified as personal qualities. Two types of such qualities may be distinguished: cognitive or intellectual competencies and personal attributes. Cognitive competencies involve the ability to analyze complex issues, to identify the core of a problem and the means of solving it, to synthesize and integrate elements. Christopher Ball elaborated the view:

"The abilities most valued in industrial, commercial and professional life as well as in public and social administration are the transferable and personal skills. These include the ability to analyze complex issues, to identify the core of a problem and the means of solving it, to synthesize and integrate disparate elements, to 
clarify values, to make effective use of numerical and other information, to work co-operatively and constructively with others, and, above all perhaps, to communicate clearly both orally and in writing." (Robin \& Webster 1989 p. 193)

Personal attributes refer to qualities like motivation, character, honesty, integrity, commitment and so on. The following has also been quoted in a recent Manpower Services Commission-sponsored "Skills for the Future" survey:

"Far greater emphasis was placed on the need for general abilities and qualities, along with personal attributes such as appearance, enthusiasm, commitment and ambition than on specific skills. Indeed, one wonders if the language of 'skills' and 'skill shortages' which so often pervades discussion linking education and employment is either useful or appropriate.... The emphasis in employers' selection criteria was overwhelmingly on the need for personal attributes in a new recruit: flexibility, initiative, reliability, honesty, interest, enthusiasm, ambition, leadership, commitment, ability to communicate and work in a team, were all stressed highly." (Robins \& Webster 1989 p. 194)

In fact the personal and moral dimensions should also be emphasized. Education discourse cannot avoid moral and spiritual issues and discussion of personal qualities such as honesty, integrity and consideration for others. In job performance, the need to face ethical issues arises constantly. It is increasingly recognized that companies as well as professional bodies need to have a code of ethics as one of the chief criteria for judging an occupation to be a profession. Professional staffs in medicine and genetics are increasingly confronted with complex moral issues. New scientific developments do not simply give humans new powers, but pose new ethical problems. If one surveys the literature about employers' expectations, one may not detect any universal pattern of technical or vocational preferences, but in general, the following are often mentioned: communication skills; analytical reasoning; lateral thinking; practical orientation; interpersonal sensitivity; motivation; emotional stability; responsibility; reliability; willingness to take up responsibilities. (Cheung 2005 p.25)

In looking for partners in running a business, it is natural not only to consider the intellectual effectiveness of the person, but also to consider personal attributes. The terms "outer life" and "inner life" have been used for thinking about a role of education in society which is not just instrumentally linked with the economy. While the "outer life" may be concerned with employment, income generation, etc., the "inner life" will be mainly concerned with personal growth, creativity, independent thought and evaluation. (Jones 1995 p. $164-165$ )

In fact, the lack of moral content is a known weakness of liberalism. As noted by Amy Gutmann, education seems to present special difficulties for liberal theories which are neutral concerning a wide range of ways of life. (Gutnamm 1987 quoted by Olssen, Codd \& Neil 2004 p. 102) Any attempt to define "good" education is likely to infringe the wishes and interests of individuals concerned. Besides, the liberals tend to take individual interests as given and not concerned about the formative development of individuals as a matter of public policy. (Olssen, Codd \& Neil 2004 p. 102) One should not be surprised to find that an economic-oriented education evolving from liberal ideologies tends to be inadequate when it comes to formation of all-rounded individuals.

In order to satisfy the needs of employers, it is clearly over-simplistic for educational planning and policy decision to focus on economic considerations. Other dimensions, such as development and nurturing of intellectual abilities, personal attributes and moral values, are equally if not more important.

\subsection{Has quality of teaching and school management been improved?}

Measures implemented by the Hong Kong Government to enhance the quality of teaching and school management include the Language Proficiency Assessment for English Language and Putonghua teachers, school-based management mechanisms applicable to all schools, kindergartens and nurseries, and also the Territory-wide System Assessment for generating school performance data. Though maybe it is still too early to comment on whether these measures are capable of generating the "quality" outcome they are expected of, what can be observed are the frequent reports in newspaper on how these initiatives are rejected and loathed by the school sector as "de-professionalization". One may jump to conclude that the school sector certainly does not welcome the increased work specifications (and probably workload as well) passed on to them by this "quality" regime, eliminating the autonomy and respect that they used to enjoy as professionals.

This phenomenon is not unique to Hong Kong. A closer look will reveal that "quality" in a market-oriented education is not related to upholding moral standard at all. It refers largely to some operational procedures of “objective setting", "planning", "performance indicator setting", "reviewing”, "internal monitoring", "external auditing" and, most important of all, "reporting". Results only count if they can be reported at the end of this series of procedures. Accountability is limited to delivering what have been laid down in objective setting. 
Professionals are valued for what they are reported having produced.

The quality regime is closely associated with the reaction of neoliberals to the time of universal welfare as discussed in Section 1.2. The neoliberals proposed the necessities for some forms of vigilance and control over indolence. This forms the basis for the neoliberal conception of a positive form of state power in ensuring all are enterprising and competitive individuals, and this has been translated into the quality control mechanisms of the quality regime. The pendulum seems to have swung to another extreme in the twenty first century.

According to Schick, although on the surface, the quality assurance procedures (which he calls contractualism) of the quality regime are meant to enhance quality by controlling indolence, he identifies the following major limitations:

6.3.1 The high costs associated with administering the system to ensure compliance

6.3.2 The weakening of collective interest and co-operative activity

6.3.3 The erosion of public service values and their replacement with self-serving values

Thus Schick concludes that "the values of the Public Service include the trust that comes from serving others, the sense of obligation that overrides personal interest, the professional commitment to do one's best, the pride associated with working in an esteemed organization, and the stake one acquires from making a career in the Public Service". (Schick 1996 p. 25) Schick's comments on Public Service are equally true to the education sector. Tim Hazeldine goes further to say that "monitoring directly diverts resources from productive activities and, more insidiously, it fosters the sort of behaviour that it is supposed to prevent. People who are systematically not trusted will eventually become untrustworthy." (Hazeldine 1998 p. 216)

Fukuyama contrasts "low-trust" societies (such as Hong Kong and Singapore) with "high-trust" societies (such as Japan and Germany). He concludes that social trust is critical to economic prosperity. This is because most business activities are carried out not by individuals pursuing their own interests but by families, partners or organizations requiring a high degree of co-operation and teamwork. The greater the level of trust within a society, the greater the propensity for co-operation. (Fukuyama 1995 p. 130 - 132)

While there is not yet evidence indicating quality of teaching and school management has been improved, the demoralization and possible de-professionalization effects of these penetrating quality enhancement measures are quite obvious, which, on the contrary, may undermine the quality of teaching and school management, and maybe economic prosperity, in the long run.

\section{Conclusion}

Nowadays there is a tendency for a subordination of education objectives to national economic goals . What lies at the root of this phenomenon is the ascendance to popularity of the classical liberal and neoliberal beliefs that the most effective way to govern a state is to apply market rules to the various aspects of state administration, including education. Though there are fundamental differences between the two different forms of liberal philosophy, the outlook of both is essentially economic. Alongside with this is the rapid advancement in technology and science since the mid-nineteenth century, which has enabled the increasingly powerful cost-benefit analysis on return to education. The emphasis on economic considerations is also the result of an intensified economic competition among nations in the recent decades.

Hong Kong is chosen as the target of a case study in this paper to evaluate the extent to which educational planning and policy decision should be guided by economic considerations. In the case study it has been shown that for the Hong Kong Government, education is largely a means for serving economic ends and this outlook is reflected throughout its educational planning and policymaking. It has also been shown that though the rapid economic growth of Hong Kong and the rapid expansion of its education system in the past decades took place in parallel, there is no clear indication that Hong Kong's economic success is a direct result of its education. Other important findings are a few major limitations of an education guided by economic principles. First, such an education is likely to be too narrow as there are many other factors, such as social capital and cultural capital, contributing to economic competitiveness. Second, an education system concentrating too much on imparting knowledge and skills needed by employers is unlikely to serve its economic purpose as what employers also want from employees are qualities associated with intellectual abilities, personal attributes and moral strength. Third, marketization of education may lead to erosion of teacher professionalism, which will, in the long run, undermine instead of enhancing the quality of education.

Wealth is to be created for human beings but human beings are not there simply for creating wealth. It is probably fair to say that education has its intrinsic values other than economic values. However, an activity 
costing over $25 \%$ of the total annual budget of Hong Kong and on average more than $13 \%$ of the total annual budgets of OECD countries can hardly escape economic scrutiny. More important is the question of how to settle priorities when so many other service are also being described by their protagonists as being "essential" or "necessary" for which we must not count the cost. Facts and figures have to be provided to support such expenditures are "different" so as to settle the struggles among the "absolutes". Moreover, economic data (such as return on investment, effectiveness of teaching in economic terms, comparative studies on global trends, etc.) should no doubt be one of the guiding indicators for educational planning and policy decision at a macro level for resource allocation, results evaluation and direction identification.

It is problematic, however, to apply economic principles at a micro level, directing in an intrusive way the priorities of institution management and classroom teaching for at least two reasons. An education focused on achieving national economic ends tends to be narrow and value neutral as discussed. Education, however, is something conducted at a personal level. As such it is bound to be diversified and value-laden. It is demoralizing for teachers if they all have to observe market rules in teaching. It is equally demoralizing for learners if they all are forced to learn in order to satisfy economic ends. One of the most cherished aims of education is enabling learners to realize their potential. A good education is there to draw out the learners' potential by helping them see their potential and cultivating in them the aspiration for achieving their best. This can only be done through putting the interests of learners at the centre of teaching, disregarding other factors, such the economic needs of the state and other stakeholders (even though the interests of learners and the economic needs of the state and other stakeholders may not be in conflict). The critical point is, if maximization of human potential can be effectively done through some form of teaching which accommodates individual needs and values, this way of teaching could well be the best way to achieve the optimal economic competitiveness.

\section{References}

Bailey, C. (1984). Beyond the present and the particular (p. 168 - 169). London: Routledge \& Kegan Paul.

Bourdieu, P. (1986) The forms of capital. In J. G. Richardson (Ed.), Handbook of theory and research for the sociology of education (p. 47, 51). Connecticut: Greenwood Press.

Census and Statistics Department (2009). Hong Kong in figures (p. 14 - 16). The Government of the Hong Kong Special Administrative Region.

Cheng, K.M. (1992). Financing education: An international perspective. In Y. P. Chung \& Y. C. Wong (Eds), The economics and financing of Hong Kong education (p. 216). Hong Kong: The Chinese University Press.

Cheung, K. Y. (2005). Enhancing personal relevance in the school curriculum (p. 25). University of London $\mathrm{PhD}$ Thesis.

Curriculum Development Council (1993a). Guide to Secondary 1 to 5 curriculum. The Government of the Hong Kong Special Administrative Region.

Curriculum Development Council (1993a). Guide to the Sixth Form curriculum. The Government of the Hong Kong Special Administrative Region.

Denison, E.F. (1962). The source of economic growth in the United States and the alternatives before us (p. 45). New York: Committee for Economic Development.

Education and Manpower Bureau (1994). The 1994 Policy Address: Education Policy Commitments (p. 12). The Government of the Hong Kong Special Administrative Region.

Education and Manpower Bureau (1995). The 1995 Policy Address: Education Policy Commitments (p. 22). The Government of the Hong Kong Special Administrative Region.

Education and Manpower Bureau (1996). The 1996 Policy Address: Education Policy Commitments (p. 30). The Government of the Hong Kong Special Administrative Region

Education Bureau (2003). Progress Report on Education Reform (2) (p. 7). The Government of the Hong Kong Special Administrative Region.

Education Commission (1990). Education Commission Report No. 4 (paragraph 6.4.7). The Government of the Hong Kong Special Administrative Region.

Education Commission (1997). Education Commission Report No. 7 (Chapter 8). The Government of the Hong Kong Special Administrative Region.

Education Commission (2000). Learning for life, learning through life. The Government of the Hong Kong Special Administrative Region. 
Fukuyama, F. (1995). Trust: The social virtues and the creation of prosperity (p. 130 - 132). London: Penguin.

Gordon, C. (1991). Government rationality: An introduction. In G.. Burchell, C. Gordon \& P. Miller (Eds). The Foucault effect (p. 44). Hemel Hempstead: Harvester Wheatsheaf.

Gray, J. (1986). Liberalism p. $x-x i)$. Buckingham: Open University Press.

Gutnamm, A. (1987). Democratic education. Princeton NJ: Princeton University Press.

Hazeldine, T. (1998). Taking New Zealand seriously (p. 216). Auckland: HaperCollins.

Jaggar, A.M. (1983). Feminist Politics and Human Nature (p. 28). Hemel Hempstead: Rowman and Allanheld/ Harvester Press.

Jones, B. (1995). Sleepers, wake!: Technology and the future of work (p. 164 - 165). Melbourne: Oxford University Press.

Kwok, K.C. (1992). An analysis of the earnings structure. In Y. P. Chung \& Y. C. Wong (Eds). The economics and financing of Hong Kong education. Hong Kong: The Chinese University Press.

Liu, P.W. (1992). Education, human capital and productivity growth of the manufacturing Industries. In Y. P. Chung \& Y. C. Wong (Eds). The economics and financing of Hong Kong education. Hong Kong: The Chinese University Press.

Moon, B., Murphy, P. \& Raynor, J. (1989). Policies for the Curriculum (p. 227). Milton Keynes: The Open University.

OECD (1987) Structural adjustment and economic performance. Organisation for Economic Cooperation and Development.

OECD (2007). Education at a glance: OECD Indicators (p. 225). Organisation for Economic Cooperation and Development.

Olssen, M., Codd, J. \& O’Neil, A.M. (2004). Education policy: Globalization, citizenship \& democracy (p. 79, 87, 102, 137). Sage Publications.

O’Neil, A.M. (1996). Privatising public policy: Privileging market man and individualising equality through choice within education in Aotearoa/New Zealand. Discourse, 17 (3) 403 - 16.

Mincer, J. (1974). Schooling, experience and earnings. New York: NBER, Columbia University Press.

Putnam, R. D. (1993). Making democracy work: Civic tradition in Italy (p. 169). Princeton: Princeton University Press.

Robins, K. \& Webster, F. (1989). The technical fix: Education, computers and Industry (p. 193-194). Basingstokes: Macmillian.

Rose, N. (1993). Government, authority and expertise in advanced liberalism. Economy and society, 22 (3), 298.

Schick, A. (1996). The spirit of reform: Managing the New Zealand state sector in a time of change (P. 25). Wellington: State Services Commission.

Schultz, T. (1960). Capital formation by education. Journal of political economy, 68 (6) $571-583$.

Tsang, Y. K. (2007). Policy Address 2007/08 by the Chief Executive The Honourable Tsang Yim Kuen (paragraph 93). The Government of the Hong Kong Special Administrative Region.

Tsang, Y. K. (2008). Policy Address 2008/09 by the Chief Executive The Honourable Tsang Yim Kuen (paragraph 49). The Government of the Hong Kong Special Administrative Region.

Tung, C. H. (1997). Policy Address 1997 by the Chief Executive The Honourable Tung Chee Hwa (paragraph 79). The Government of Hong Kong Special Administrative Region.

Tung, C. H. (1998). Policy Address 1998 by the Chief Executive The Honourable Tung Chee Hwa (paragraph 89, 106 - 108). The Government of Hong Kong Special Administrative Region.

Tung, C. H. (1999). Policy Address 1999 by the Chief Executive The Honourable Tung Chee Hwa (paragraph 52, 69, 77). The Government of Hong Kong Special Administrative Region.

Tung, C. H. (2000). Policy Address 2000 by the Chief Executive The Honourable Tung Chee Hwa (paragraph 53 - 56, 66, 69). The Government of Hong Kong Special Administrative Region.

Tung, C. H. (2001). Policy Address 2000 by the Chief Executive The Honourable Tung Chee Hwa (paragraph 54). The Government of Hong Kong Special Administrative Region. 
Tung, C. H. (2003). Policy Address 2003 by the Chief Executive The Honourable Tung Chee Hwa (paragraph 20). The Government of Hong Kong Special Administrative Region.

Tung, C. H. (2004). Policy Address 2004 by the Chief Executive The Honourable Tung Chee Hwa (paragraph 43). The Government of Hong Kong Special Administrative Region.

Tung, C. H. (2005). Policy Address 2005 by the Chief Executive The Honourable Tung Chee Hwa (paragraph 56). The Government of Hong Kong Special Administrative Region.

University Grant Commission (1996). Higher education in Hong Kong. The Government of the Hong Kong Special Administrative Region.

West, E.G. (1994). Education and the state: A study in political economy (p. 114, 117 - 118). (3 ${ }^{\text {rd }}$ Ed.). Liberty Fund.

Wong, K.F. (1992). Private and social rate of return to investment in education. In Y. P. Chung \& Y. C. Wong (Eds). The economics and financing of Hong Kong education. Hong Kong: The Chinese University Press.

\section{Notes}

Note 1: See Department of Education and Science (1982) Teaching training and preparation for work life (p. 1). HMSO. This is also quoted by Bailey (1984), p. 168

Note 2: See Department of Education and Science (1980) A frame for school curriculum (p. 8). HMSO This is also quoted by Bailey (1984), p. 169

Note 3: Extracts from Margaret Thatcher's speech to the Conservative Party conference in 1987. This can be found in Moon, Murphy \& Raynor (1989) p. 227

Note 4: The Hong Kong Government adopted a policy of free and compulsory universal primary education for all in 1971. By 1980 compulsory education was extended to Secondary Three. The Hong Kong Polytechnic was established in 1970 and the City Polytechnic of Hong Kong was established in 1984.

Note 5: Available on official website of World Economic Forum:

http://www.weforum.org/en/initiatives/gcp/Global\%20Competitiveness\%20Report/PastReports/index.htm

Note 6: Bourdieu defines social capital as "the aggregate of the actual or potential resources which are linked to possession of a durable network of more or less institutionalized relationships of mutual acquaintance and recognition." (Bourdieu 1986 p.51) According to Putnam, there are three essential components in social capital: trust, norms and networks (Putnam 1993 p. 169)

Note 7: Cultural capital refers the knowledge, experience and or connections one has had through the course of their life that enables them to succeed more so than someone from a less experienced background (Wikipedia). According to Bourdieu, there are three types of cultural capital: embodied, objectified and institutionalized. (Bourdieu, 1986 p. 47).

Table 1. Projected manpower resource balance by educational attainment in 2005 (Hong Kong Government 2000)

\begin{tabular}{|l|l|l|l|}
\hline Educational attainment & Supply & Requirement & Balance \\
\hline Lower secondary and below & 1202200 & 1065000 & +136700 \\
\hline Upper secondary & 1120200 & 1105000 & +15200 \\
\hline Craft & 32100 & 24700 & +7400 \\
\hline Post-secondary & 535600 & 621200 & -85500 \\
\hline First degree and above & 485400 & 516700 & -31400 \\
\hline
\end{tabular}

Table 2. The rates of return to higher education of men in Hong Kong in 1976 and 1986 (Wong 1992).

\begin{tabular}{|l|l|l|l|l|}
\hline \multirow{2}{*}{ Level of education } & \multicolumn{1}{|l|}{1976} & $\mathbf{1 9 8 6}$ & Social rate of return \\
\cline { 2 - 5 } & Private rate of return & Social rate of return & Private rate of return & $9.6 \%$ \\
\hline Upper secondary & $17.9-18 \%$ & $14.1-15.3 \%$ & $12.1 \%$ & $10.6 \%$ \\
\hline Matriculation & $24.8 \%$ & $22.5 \%$ & $13.9 \%$ & $11.9 \%$ \\
\hline University & $15.1 \%$ & $5.3 \%$ & $26.9 \%$ & \\
\hline
\end{tabular}

